\title{
De rol van emoties in narratieve overtuiging
}

\section{Inleiding}

Empirisch onderzoek heeft in de afgelopen jaren laten zien dat verhalen invloed kunnen hebben op wat mensen voor waar houden, op wat ze goed vinden en zelfs op hoe ze zich gedragen. ${ }^{1}$ Die invloed is aangetoond voor films (bijv. Igartua, 2010; Igartua \& Barrios, 2012), korte verhalen (bijv. De Graaf, Hoeken, Sanders \& Beentjes, 2007; Green \& Brock, 2000), afleveringen van populaire televisieseries zoals Law \& Order (Slater, Rouner \& Long, 2006) en Sex and the city (Moyer-Gusé, Chung \& Jain, 2011) en boeketreeks romans (Diekman, McDonald \& Gardner, 2000). De effecten van verhalen blijken bovendien relatief langdurig (Appel \& Richter, 2007) en onafhankelijk van de vraag of het om verzonnen of waargebeurde verhalen gaat (Appel \& Maleckar, 2012; Green \& Brock, 2000).

$\mathrm{Nu}$ de potentiële overtuigingskracht van verhalen is aangetoond, verschuift de aandacht naar de mechanismen waarlangs verhalen hun effect sorteren. In dit onderzoek richten wij ons op de rol van door het verhaal opgeroepen emoties in het narratieve overtuigingsproces. Deze emoties lijken een belangrijke kandidaat voor het verklaren van de persuasieve kracht van verhalen omdat in eerdere onderzoeken een sterke relatie gerapporteerd werd tussen dergelijke emoties en de uiteindelijke attitudes van de proefpersonen (Busselle \& Bilandzic, 2009; De Graaf, Hoeken, Sanders \& Beentjes, 2009). Bij deze studies werd de intensiteit van ervaren emoties echter geobserveerd in plaats van gemanipuleerd. Het is daardoor onduidelijk in hoeverre deze emoties een noodzakelijke voorwaarde

\section{Samenvatting}

Er is veel onderzoek dat laat zien dat verhalen de attitude van het publiek kunnen beïnvloeden. In dit onderzoek richten we ons op de vraag of de persuasieve werking van verhalen mede het gevolg is van emoties die worden opgeroepen doordat het publiek zich identificeert met het personage. In een experiment werd de mate van identificatie met een personage gemanipuleerd door het personage als minder of meer sympathiek af te schilderen. Dit verschil in identificatie leidde niet alleen tot het in sterkere mate ervaren van emoties maar ook tot een positievere attitude. Uit verdere analyses bleek dat het effect op de attitude niet alleen gemedieerd werd door de mate waarin het verhaal emoties had opgeroepen, welk effect op haar beurt weer gemedieerd werd door identificatie, maar ook de mate waarin men het verhaal als geloofwaardig beschouwde. Hiermee werpt dit onderzoek licht op een belangrijk mechanisme van narratieve overtuiging. 
vormen voor het optreden van een overtuigingseffect dan wel slechts een bijproduct vormen van het gebruik van een verhaal, maar verder geen rol spelen bij de beïnvloeding van opinies en attitudes. In dit onderzoek proberen we de vraag te beantwoorden of emoties daadwerkelijk een mediërende rol spelen in het narratieve overtuigingsproces.

1.1 De rol van identificatie in narratieve overtuiging Er bestaan verschillende modellen die de overtuigende werking van verhalen pogen te verklaren zoals het Transportation Imagery Model van Green en Brock (2002), het Extended Elaboration Likelihood Model van Slater en Rouner (2002) en het Entertainment Overcoming Resistance Model van Moyer-Gusé (2008). In al deze modellen wordt het gevoel van je te verliezen in de wereld van het verhaal als een cruciale voorwaarde voor narratieve overtuiging beschouwd. Deze ervaring wordt met verschillende benamingen aangeduid zoals transportatie (Green \& Brock, 2002; Moyer-Gusé, 2008), absorptie (Slater \& Rouner, 2002) en narratieve betrokkenheid (Busselle \& Bilandzic, 2009). Ondanks deze verschillende benamingen zijn de onderzoekers het grotendeels eens over wat deze ervaring behelst: een getransporteerd publiek richt zijn aandacht volledig op de door het verhaal opgeroepen wereld en vergeet zijn directe omgeving, waant zich aanwezig bij de beschreven gebeurtenissen en ervaart emoties als gevolg van het wedervaren van de personages in het verhaal.

Als gevolg van deze ervaring kan het verhaal op verschillende manieren de attitude van het publiek beïnvloeden. In de eerste plaats kan het publiek zijn kritische vermogens verliezen. Waar een brochure over de gevaren van drugsgebruik weerstand oproept bij, en geridiculiseerd wordt door een jeugdige doelgroep, zou dezelfde boodschap wel effect sorteren bij (sommige leden van) de doelgroep als ze een boek als Kappen van Carry Slee lezen. Het idee is dat lezers die zich verliezen in een verhaal niet in staat en/of gemotiveerd zijn om kritisch te reageren op de anti-drugs boodschap van dat boek (Green \& Brock, 2002; Moyer-Gusé, 2008; Slater \& Rouner, 2002). Green en Brock (2002) stellen daarnaast dat geschreven verhalen dermate levendige beelden op kunnen roepen dat het publiek het optreden van een dergelijke gebeurtenis waarschijnlijker acht. Zo zou volgens hen een levendige beschrijving van een vliegtuigramp mensen ervan kunnen overtuigen dat vliegen een gevaarlijke manier van reizen is.

In dit onderzoek richten wij ons op een derde wijze waarop verhalen effect kunnen sorteren, namelijk de band die het publiek vormt met personages. In het onderzoek naar narratieve overtuiging wordt deze band vaak aangeduid als identificatie met het personage. Cohen (2001) omschrijft identificatie als bestaande uit affectieve empathie (het vermogen om te ervaren wat het personage ervaart), cognitieve empathie (het perspectief van het personage overnemen), het internaliseren van de doelen van het personage en, in het meest extreme geval, het gevoel hebben dat je het personage wordt. De empirische evidentie voor de rol van identificatie groeit snel. In een reeks onderzoeken wordt de invloed van het zien van een film of aflevering van een televisieserie vergeleken met een controlegroep die een andere film of aflevering ziet waarin het onderzochte thema niet voorkomt. Zo laten MoyerGusé en Nabi (2010) zien dat identificatie met een personage uit een televisieserie invloed kan hebben op het waargenomen risico op een tienerzwangerschap en op de intentie om veilig te vrijen. Moyer-Gusé et al. (2011) tonen aan dat het praten over seksueel overdraagbare aandoeningen met voormalige partners beïnvloed kan worden door te kijken naar een aflevering van Sex and the City. Identificatie met personages in films kan leiden tot het aanpassen van overtuigingen over kerkelijke zaken (Igartua, 2010; Igartua \& Barrios, 2012), de 
acceptatie van psychiatrische patiënten (Caputo \& Rouner, 2011) en attitudes ten opzichte van de doodstraf (Till \& Vitouch, 2012).

De vraag is nu hoe identificatie met een personage invloed heeft op de opinies van het publiek. Green en Donahue (2009, p. 247) schetsen twee mogelijke mechanismen. In de eerste plaats kunnen als gevolg van identificatie met een personage de opinies van dat personage meer gewicht krijgen voor het publiek. De Graaf, Hoeken, Sanders en Beentjes (2012) laten zien hoe dit werkt. In één van hun experimenten werd het verhaal verteld van twee zussen wier moeder in een onomkeerbare coma ligt. Eén zus vraagt zich af of haar moeder wel zo door zou willen leven en wil de mogelijkheid van euthanasie bespreken. De andere zus wil daar niet eens over nadenken. Er waren twee verhaalversies die volledig identiek waren op de expliciet naar voren gebrachte opinie van de hoofdpersoon na: in één versie was de hoofdpersoon vóór het overwegen van euthanasie, in de andere was ze faliekant tegen. De Graaf et al. laten zien dat proefpersonen zich in sterkere mate identificeerden met de hoofdpersoon dan met de antagonist en dat ze als gevolg van die sterkere identificatie het ook in sterkere mate eens waren met het door de hoofdpersoon ingenomen standpunt. Ze waren dus meer (of minder) geneigd om in dit soort gevallen euthanasie te overwegen, afhankelijk van het standpunt van het personage waar ze zich het sterkst mee identificeerden.

Het tweede mechanisme waaraan Green en Donahue (2009) refereren betreft de invloed die het overnemen van de doelen van een personage kan hebben voor de attitude van het publiek ten opzichte van bepaalde obstakels. Het andere door De Graaf et al. (2012) gerapporteerde experiment biedt evidentie voor dat mechanisme. Proefpersonen lazen een verhaal over een noodlijdend bedrijf dat een vacature wil vervullen en een gehandicapte sollicitant die dolgraag die baan wil. In één versie was de sollicitant de hoofdpersoon, in de andere versie de manager van het bedrijf. De proefpersonen dachten positiever over het recht van bedrijven om geschikte gehandicapte sollicitanten af te wijzen als ze de versie hadden gelezen waarin de manager de hoofdpersoon was in vergelijking met de versie waarin de sollicitant de hoofdpersoon was. Opnieuw bleek de mate van identificatie met de manager (of de sollicitant) een mediërende rol te spelen bij het optreden van dit effect. Het recht om gehandicapte sollicitanten af te wijzen kwam op geen enkele wijze expliciet aan de orde in het verhaal. Daarmee verschilt het van het andere experiment waarin het standpunt ten opzichte van het overwegen van euthanasie wél expliciet naar voren werd gebracht. Het was echter wel duidelijk dat dit recht strookte met het belang van de manager en juist inging tegen dat van de sollicitant.

Cohen (2001) noemt affectieve empathie, het kunnen navoelen wat het personage voelt, als één van de kenmerken van identificatie. De proefpersonen in het experiment van De Graaf et al. (2012) konden zich waarschijnlijk voorstellen dat de sollicitant boos en verdrietig zou zijn als hij de baan niet zou krijgen.Vanuit die negatieve emoties zouden ze ook een negatieve attitude kunnen vormen ten opzichte van regelgeving die het bereiken van het doel door de sollicitant in de weg staat. De Graaf et al. (2012) hebben in hun onderzoek echter geen emoties gemeten. Daardoor is het niet mogelijk om deze verklaring te toetsen.

Er zijn wel aanwijzingen dat door het wedervaren van personages opgeroepen emoties een belangrijke rol spelen bij narratieve overtuiging. Busselle en Bilandzic (2009) laten zien dat de (door personages opgeroepen) emoties het sterkst gecorreleerd waren met de uiteindelijke attitude van het publiek. Ook De Graaf et al. (2009) rapporteren dat de mate van identificatie met een asielzoekster en de daaruit voortvloeiende emoties het sterkst gecorreleerd zijn met de attitude ten opzichte van de asielprocedures. In deze studies zijn de emoties 


\section{De rol van emoties in narratieve overtuiging}

gemeten maar niet gemanipuleerd. Daardoor valt niet uit te sluiten dat een negatievere attitude ten opzichte van de asielprocedure heeft geleid tot intensere emoties in plaats van andersom. In deze studie proberen we daarom de vraag te beantwoorden of een sterkere mate van identificatie met een personage inderdaad leidt tot het ervaren van intensere emoties die op hun beurt gevolgen hebben voor de attitude van het publiek.

1.2 Onderzoekshypothesen Om de complexe keten tussen identificatie, emoties en attitude te onderzoeken, was het noodzakelijk om de mate van identificatie te beïnvloeden. Daartoe werd de mate waarin het personage als sympathiek werd ervaren gemanipuleerd. Raney (2004) stelt dat mensen zich in sterkere mate identificeren met een sympathiek personage. Tal-Or en Cohen (2010) lieten zien dat dit inderdaad het geval was; in hun onderzoek identificeerden proefpersonen zich in sterkere mate met een sympathiek personage dan met een onsympathiek personage. Dit leidt tot de eerste hypothese:

H1: Proefpersonen identificeren zich in sterkere mate met een sympathiek dan met een onsympathiek personage.

Cohen (2001) voorspelt dat een sterkere mate van identificatie leidt tot het sterker ervaren van door het personage ervaren emoties.

H2: Het verhaal met een sympathiek personage roept sterkere emoties op dan het verhaal met een onsympathiek personage.

Als deze emoties inderdaad een spilfunctie vervullen in het narratieve overtuigingsproces, dan zouden die emoties ook gevolgen moeten hebben voor de attitude.

H3: Het verhaal met een sympathiek personage heeft een sterkere invloed op de attitude dan het verhaal met een onsympathiek personage.

Als de bovenstaande hypotheses worden bevestigd, kan daar niet uit worden afgeleid dat het effect van het karakter van het personage op de attitude het gevolg is van de grotere mate van identificatie en ervaren emoties. Daarvoor is een aanvullende mediatie-analyse nodig (Preacher \& Hayes, 2008). Met behulp van een mediatie-analyse kan worden vastgesteld of het effect van de manipulatie op de uiteindelijke variabele (in dit geval: de attitude) verklaard kan worden door de veronderstelde tussenliggende variabelen (in dit geval: de emoties en identificatie).

H4: Het effect van de karaktermanipulatie op de attitude wordt gemedieerd door identificatie en emoties.

Bovenstaande hypotheses werden getoetst middels een experiment waarin twee versies van een verhaal werden aangeboden die enkel verschilden wat betreft de mate waarin het hoofdpersonage als sympathiek werd geportretteerd. 
2.1 Materiaal Het materiaal werd gepresenteerd als een nieuwsbericht over de gevolgen van de bezuinigingen op de Algemene Wet Bijzondere Zorg voor mensen met een persoonsgebonden budget. In een korte inleiding werd ingegaan op de kabinetsplannen (van het kabinet Rutte 1) om te bezuinigen op de zogenaamde PGBs (persoonsgebonden budgetten). Daarna volgde het verhaal over Loes ter illustratie van de gevolgen die deze bezuinigingen zouden kunnen hebben. Het verhaal was gebaseerd op een verhaal uit de brochure 'Zo hebben we het goed thuis!' met als ondertitel: 'Bezuinigingen op de AWBZ: Kunnen mensen met grote zorgvraag straks nog wel thuis blijven wonen?' uitgegeven door Per Saldo, de belangenvereniging van mensen met een PGB.

Loes is een vrouw van 45 jaar die na een aanrijding kampt met klachten naar aanleiding van hersenletsel. Om zelfstandig thuis te kunnen wonen, maakt zij aanspraak op een PGB. Zonder PGB zou zij gedwongen zijn om in een verzorgingstehuis te gaan wonen. Om de mate van identificatie te beïnvloeden, werd Loes als meer of minder sympathiek neergezet. In de sympathieke versie gaat zij vriendelijk om met de mensen die haar helpen en geeft zij het deel van het PGB dat ze overhoudt omdat ze slim zorg inkoopt, terug aan de overheid. In de onsympathieke versie is Loes onvriendelijk tegen de mensen die haar helpen en houdt zij het overgebleven deel van het budget voor zichzelf. Hieronder staan twee gemanipuleerde fragmenten uit de tekst:

\begin{tabular}{|l|l|}
\hline Sympathieke versie & Onsympathieke versie \\
\hline 'Elke ochtend komt iemand van de thuiszorg mij hel- & 'Elke ochtend komt iemand van de thuiszorg mij hel- \\
pen met wassen en aankleden. Als we op tijd klaar zijn, \\
drink ik samen met de hulp een kop koffie en ma- \\
ken we een praatje. Op maandag en donderdag komt \\
thuishulp direct naar huis. Koffie drinkt ze maar in \\
haarna een vriendin. Ik heb haar vijfentwintig jaar ge- \\
leden ontmoet. Zij doet het huishouden en rijdt mij \\
naar medische afspraken. Ik betaal haar uit mijn PGB. \\
het is een groot voorrecht dat ik haar uit mijn PGB niet voor! Op maan- \\
kan en magh betalen.'
\end{tabular}

Behalve het karakter van het personage werd ook de mate van uitgewerktheid van het personage gemanipuleerd. Voor zowel de versie met het onsympathieke personage als die met het sympathieke personage werden een meer beknopte en een meer uitgebreide versie geschreven. De aanvullende informatie was voor alle versies gelijk en zou de proefpersonen in de gelegenheid moeten stellen om zich in sterkere mate te identificeren met het personage. Uit de resultaten bleek de mate van uitgewerktheid echter geen invloed te hebben, niet op zichzelf noch in interactie met de manipulatie van het personage; ook de beknopte versie bleek proefpersonen in staat te stellen om zich een beeld te vormen van de hoofdpersoon. Deze variabele is daarom verder buiten beschouwing gelaten in dit artikel. 
2.2 Proefpersonen, procedure en onderzoeksontwerp In total deden 151 proefpersonen mee aan het onderzoek. Hun leeftijd varieerde van 16 tot 70 jaar, met een gemiddelde van 35,8 jaar. Iets meer vrouwen $(50,3 \%)$ dan mannen namen deel aan het onderzoek. De proefpersonen werden per email benaderd met de vraag of ze wilden deelnemen aan een onderzoek naar de waardering voor verhalen. Als ze instemden, dan kregen ze een link naar een website toegestuurd waarna ze random één van de versies van het verhaal te lezen kregen. Nadat ze het verhaal hadden gelezen en de vragenlijst beantwoord, kregen ze informatie over het doel van het onderzoek. Een experimentele sessie duurde gemiddeld 11,5 minuut.

2.3 Instrumentatie In de vragenlijst werden de verschillende afhankelijke variabelen met behulp van zevenpunts semantische differentialen of Likert schalen gemeten. De attitude ten opzichte van PGB werd gemeten met behulp van vier semantische differentialen (bijv. goed - slecht, onverstandig - verstandig) voorafgegaan door de frase: 'Als het PGB in zijn geheel zou worden afgeschaft, dan vind ik dat'. De betrouwbaarheid van de schaal was goed: Cronbach's $\alpha=.91$. De scores op deze items werden zo omgecodeerd dat een hogere score een positievere attitude ten opzichte van het PGB impliceerde.

De waardering voor het verhaal werd gemeten met behulp van vijf Likert-items ontleend aan Hartmann en Vorderer (2009): 'Het lezen van het verhaal over Loes vond ik interessant' of 'tijdverspilling' $(\alpha=.76)$.

Vervolgens werden 21 aan Banerjee en Greene (2012) ontleende items gebruikt om de door het verhaal opgeroepen emoties te meten. Een factoranalyse van deze items leidde tot de identificatie van vier factoren: zes items over positieve emoties (blij, ontspannen: $\alpha=.92$ ), zes items over passieve negatieve emoties (verdrietig, bezorgd: $\alpha=.86$ ), drie items over meer actieve negatieve emoties (boos, geïrriteerd: $\alpha=.76$ ) en drie items die verrassing meten (verrast, geschokt: $\alpha=.81$ ).

De mate waarin het personage sympathiek werd gevonden, werd bevraagd met vier Likert items gebaseerd op Moyer-Gusé (2008): 'Ik vond Loes aardig' en 'Ik vond Loes een sympathiek persoon' $(\alpha=.92)$.

De mate van narratieve betrokkenheid werd gemeten met behulp van een schaal ontwikkeld door De Graaf et al. (2012). Met behulp van zes items werd gemeten in welke mate de proefpersonen zich identificeerden met Loes ('Tijdens het lezen, heb ik meegeleefd met Loes'; $\alpha=.88$ ), met zeven items werd de mate gemeten waarin de proefpersonen zich de in het verhaal geschetste gebeurtenissen konden voorstellen ('Terwijl ik het verhaal las, zag ik voor me wat er in het verhaal beschreven werd'; $\alpha=.87)$ en ten slotte werd met vier items gemeten in welke mate de aandacht van de lezer op het verhaal was gericht $(\alpha=.71)$.

Als laatste werd gemeten in welke mate de proefpersonen het verhaal als geloofwaardig ervoeren. Hierbij werden vijf items vertaald die ontwikkeld waren door Canter, Nicol en Benneworth (2003), bijvoorbeeld: Ik vond het verhaal 'niet geloofwaardig - geloofwaardig' $(\alpha=.83)$.

2.4 Statistische toetsing Voor de toetsing van de hypotheses met betrekking tot het effect van de karaktermanipulatie van het personage (hypotheses 1 tot en met 3) werd gebruik gemaakt van t-toetsen.Voor het toetsen van de mediatie-analyse (hypothese 4) werd gebruik gemaakt van het script voor een multiple mediator analyse ontwikkeld door Preacher en Hayes (2008). 
In de eerste plaats werd onderzocht of de manipulatie van het karakter van het personage het gewenste effect had gehad. Idealiter zou het sympathieke personage aardiger worden gevonden dan het onsympathieke personage, maar zouden beide versies van het verhaal in gelijke mate de aandacht van de proefpersonen hebben vastgehouden, als even realistisch worden beschouwd en evenveel plezier en beelden hebben opgeroepen. In Tabel 1 staan de scores voor deze afhankelijke variabelen weergegeven.

Tabel 1: De gemiddelde scores (en standaarddeviaties) voor de controlevariabelen als functie van het karakter van het personage (1 = zeer negatief / zeer mee oneens, 7 = zeer positief / zeer mee eens) en de resultaten van de statistische toetsing

\begin{tabular}{|c|c|c|c|c|c|c|c|c|c|}
\hline & \multicolumn{3}{|c|}{ Sympathiek } & \multicolumn{6}{|c|}{ Onsympathiek } \\
\hline & $\mathbf{M}$ & SD & $\mathbf{n}$ & $\mathbf{M}$ & SD & $\mathbf{n}$ & $t$ & df & $p$ \\
\hline Waardering personage & 4.47 & 0.85 & 77 & 3.13 & 1.05 & 74 & 8.69 & 149 & $<.01$ \\
\hline \multicolumn{10}{|l|}{ Narratieve betrokkenheid } \\
\hline Aandacht & 4.26 & 0.94 & 77 & 4.20 & 1.18 & 74 & 0.31 & 149 & $=.76$ \\
\hline Beeldend & 4.47 & 1.19 & 77 & 4.32 & 0.89 & 74 & 0.88 & 149 & $=.38$ \\
\hline Geloofwaardigheid verhaal & 5.17 & 1.09 & 77 & 4.42 & 0.88 & 74 & 4.66 & 149 & $<.01$ \\
\hline Waardering verhaal & 4.54 & 1.02 & 77 & 4.15 & 1.01 & 74 & 2.34 & 149 & $<.05$ \\
\hline
\end{tabular}

De manipulatie van het karakter van het personage had het gewenste effect dat het sympathieke personage (veel) aardiger werd gevonden dan het onaardige personage zonder dat de manipulatie de mate van aandacht voor het verhaal of de mate waarin het verhaal beelden opriep beïnvloedde. Daarentegen werd het verhaal met het sympathieke personage wel als geloofwaardiger ervaren en werd deze versie in sterkere mate gewaardeerd.

De hypotheses 1 tot en met 3 voorspellen dat proefpersonen die de versie met het sympathieke personage hebben gelezen zich in sterkere mate met dat personage zouden identificeren, negatievere emoties ervaren als gevolg van de mogelijke opheffing van het PGB en een positievere attitude ten opzichte van het PGB ontwikkelen. In Tabel 2 staan de scores voor deze afhankelijke variabelen.

Tabel 2: De gemiddelde scores (en standaarddeviaties) voor de afhankelijke variabelen als functie van het karakter van het personage ( 1 = zeer negatief/zeer mee oneens, 7 = zeer positief/zeer mee eens) en de resultaten van de statistische toetsing. Positieve emoties

\begin{tabular}{|c|c|c|c|c|c|c|c|c|c|}
\hline & \multicolumn{3}{|c|}{ Sympathiek } & \multicolumn{6}{|c|}{ Onsympathiek } \\
\hline & $\mathbf{M}$ & SD & $\mathbf{n}$ & $\mathbf{M}$ & SD & $\mathbf{n}$ & $t$ & df & $p$ \\
\hline Identificatie & 4.11 & 1.01 & 77 & 3.51 & 0.89 & 74 & 3.88 & 149 & $<.001$ \\
\hline \multicolumn{10}{|l|}{ Emoties } \\
\hline Positieve & 2.88 & 1.09 & 77 & 3.24 & 1.09 & 74 & 2.09 & 149 & $<.05$ \\
\hline Negatieve & 3.80 & 1.30 & 77 & 3.17 & 1.31 & 74 & 2.96 & 149 & $<.01$ \\
\hline Boosheid & 4.25 & 1.33 & 77 & 4.44 & 1.14 & 74 & 0.94 & 149 & $=.35$ \\
\hline Verrassing & 3.80 & 1.35 & 77 & 3.85 & 1.41 & 74 & 0.22 & 149 & $=.82$ \\
\hline Attitude & 6.17 & 0.95 & 77 & 5.87 & 1.03 & 74 & 1.91 & 149 & $<.05^{\star}$ \\
\hline
\end{tabular}

* eenzijdig getoetst 


\section{De rol van emoties in narratieve overtuiging}

De resultaten zijn grotendeels in lijn met de hypotheses. Na lezing van de versie met het sympathieke personage, identificeerden proefpersonen zich in sterkere mate met het personage.Voor twee van de vier emotiegroepen trad ook het verwachte effect op. Als het sympathieke personage haar PGB dreigde te verliezen, ervoeren de proefpersonen in mindere mate positieve emoties en in sterkere mate negatieve emoties dan na lezing van de versie met het onsympathieke personage; voor boosheid en verrassing maakte dit geen verschil. Ten slotte bleek, bij eenzijdige toetsing, dat proefpersonen een positievere attitude ten opzichte van de PGB hadden na lezing van de versie met het sympathieke personage dan na lezing van de versie met het onsympathieke personage.

Hypothese 4 voorspelde dat de manipulatie van het karakter van het personage zou leiden tot een sterkere mate van identificatie met dat personage wat op zijn beurt zou leiden tot sterkere emoties die uiteindelijk een positievere attitude tot gevolg zouden hebben. Uit de analyse blijkt dat de manipulatie inderdaad invloed heeft gehad op de mate van identificatie, ervaren emoties en de attitude, maar daarnaast bleek de manipulatie óók de geloofwaardigheid van het verhaal en de waardering voor het verhaal te hebben beïnvloed. Zeker voor de geloofwaardigheid van het verhaal (Cho, Shen \& Wilson, in druk) geldt dat ook die verantwoordelijk kan zijn voor het uiteindelijke effect op de attitude. Het is immers mogelijk dat de grotere geloofwaardigheid van het verhaal met het sympathieke personage verantwoordelijk is voor de grotere impact van die versie op de attitude. Om hypothese 4 te toetsen, is daarom gebruik gemaakt van de (bootstrap) multiple mediator methode ontwikkeld door Preacher en Hayes (2008). Met behulp van deze methode is het mogelijk om tegelijkertijd voor verschillende potentiële mediatorvariabelen vast te stellen welke van deze variabelen daadwerkelijk verantwoordelijk is voor het optreden van het uiteindelijke effect op de attitude. Daartoe wordt getoetst of het effect van de onafhankelijke variabele op de uiteindelijke afhankelijke variabele verdwijnt als er gecontroleerd wordt voor het indirecte effect van (1) de onafhankelijke variabele op de mediator variabele (bijv. emoties) en (2) het effect van de mediatorvariabele op de afhankelijke variabele (attitude). Een significant indirect effect geeft aan dat het effect inderdaad verloopt via de veronderstelde mediërende variabele.

In de eerste stap werd onderzocht welke variabelen een mediërende rol hadden gespeeld bij het effect van de personagemanipulatie op de attitude. Daartoe werden de manipulatie van het personage als onafhankelijke variabele, de attitude als afhankelijke variabele en alle potentiële mediatorvariabelen (identificatie, negatieve emoties, positieve emoties, geloofwaardigheid, waardering) als mediatorvariabelen ingevoerd. Uit deze analyse kwam naar voren dat alleen de negatieve emoties $(B=0.13$, se: $0.06, z=2.20, p<.05)$ én de waargenomen geloofwaardigheid het effect van de manipulatie op de attitude hadden gemedieerd $(B=0.18$, se: $0.07, z=2.51, p<.05)$. De andere variabelen (identificatie: $z=1.34, p=.18$; positieve emoties: $z=0.24, p=.81$; waardering: $z=0.68, p=.50$ ) bleken geen mediërende rol te spelen. In de tweede analyse werd onderzocht welke variabelen een mediërende rol hadden gespeeld bij het oproepen van negatieve emoties.Van de potentiële mediatoren bleek alleen identificatie een mediërende rol te hebben gespeeld $(B=0.28$, se: $0.10, z=2.90, p$ $<.01)$ terwijl dat niet gold voor de waardering voor $(z=1.01, p=.31)$ of waargenomen geloofwaardigheid van het verhaal $(z=1.10, p=.27)$. Figuur 1 geeft de resultaten van deze analyse grafisch weer. 


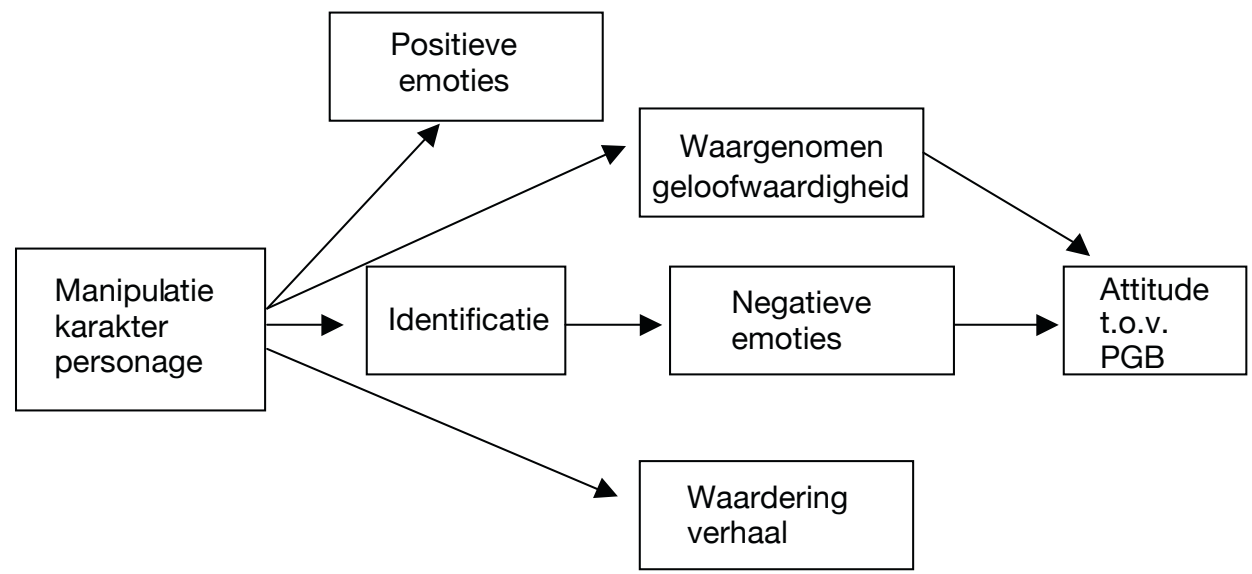

Figuur 1: Grafische weergave resultaten mediatie-analyse

\section{Discussie}

De resultaten van dit onderzoek laten zien dat door een verhaal opgeroepen emoties een belangrijke rol kunnen spelen bij het optreden van narratieve persuasieve effecten. Naarmate lezers zich in sterkere mate identificeren met een personage, ervaren ze intensere emoties als het welzijn van dat personage wordt bedreigd, bijvoorbeeld als gevolg van het afschaffen van een bepaalde subsidie, en vormen ze een positievere attitude ten opzichte van die subsidie. Waar in eerder onderzoek vooral het belang van door het verhaal opgeroepen emoties voor de overtuigingskracht op basis van correlationele gegevens werd onderbouwd, zijn we er in dit onderzoek in geslaagd om verschillen in ervaren emoties te manipuleren en laten we zien dat deze emoties het effect op de attitude mediëren.

$\mathrm{Nu}$ de rol van emoties voor narratieve overtuiging is vastgesteld, wordt de vraag relevant welke verhaalkenmerken tot verschillen in ervaren emoties leiden. De in dit onderzoek gehanteerde manipulatie laat daarbij twee mogelijkheden open. In de beschrijving van het personage werden twee aspecten gemanipuleerd: het personage was vriendelijk of onvriendelijk tegen de mensen die haar hielpen én ze stak het overgebleven deel van het PGB in haar eigen zak of stortte dat bedrag terug. In de versie met het onsympathieke personage konden de proefpersonen zich moeilijker identificeren met het personage waardoor ze minder sterke emoties ervoeren als gevolg van verminderde affectieve empathie. Het effect van deze manipulatie kan echter ook op een andere manier worden verklaard. De negatieve emoties zouden in minder sterke mate worden opgeroepen doordat het afschaffen van het PGB als een rechtvaardige straf kan worden gezien voor het personage dat het overgebleven bedrag in eigen zak heeft gestopt.

De mate waarin de afloop van een verhaal als rechtvaardig wordt gezien, speelt een belangrijke rol in modellen voor het verklaren van het plezier dat we beleven aan (o.a.) verhalen. Zo beargumenteert Raney (2004) dat de aard en de intensiteit van door verhalen opgeroepen emoties afhangen van de mate waarin de afloop strookt met het 'just world belief': het geloof dat de wereld rechtvaardig in elkaar zit.Volgens Raney beleven mensen met name plezier aan verhalen waarvan de afloop in overeenstemming is met een rechtvaardige wereld 


\section{De rol van emoties in narratieve overtuiging}

waarmee wordt bedoeld dat het goede beloond en het kwade bestraft wordt. Volgens Raney roept een verhaal positieve emoties (blijdschap, tevredenheid) op als het goed afloopt met de held (en slecht met de schurk) en roept het negatieve emoties op (verdriet, boosheid) als het daarentegen slecht afloopt met goede personages (of goed met slechte personages). Hoeken (2009) laat zien hoe politici hun publiek de onrechtvaardigheid van bepaalde maatregelen laten 'voelen' door anekdotes te gebruiken waarin het slecht afloopt met een goed personage als gevolg van de gewraakte maatregel.

Het model van Raney (2004) biedt een alternatieve verklaring voor hoe het verschil in ervaren emoties is opgeroepen. De opheffing van het PGB zou als een rechtvaardige straf kunnen worden gezien voor het (gedeeltelijke) misbruik ervan in de verhaalversie met het onsympathieke personage. Of men de opheffing van het PGB ook als een rechtvaardige straf beschouwt voor het onvriendelijk bejegenen van verpleegkundigen is een andere vraag. In vervolgonderzoek zou de manipulatie van het karakter van het personage op een eenduidiger manier moeten gebeuren én de mate waarin de afloop van het verhaal als rechtvaardig wordt beschouwd moeten worden gemeten. Met een dergelijke opzet wordt het mogelijk om te toetsen of de mate waarin een verhaal emoties oproept vooral het gevolg is van de mate waarin men zich identificeert met het verhaalpersonage óf van de mate waarin de afloop van het verhaal als rechtvaardig wordt ervaren. Kortom: wordt vervolgd.

\section{Noot}

1 Dit paper is gebaseerd op het onderzoek dat Jop Sinkeldam heeft uitgevoerd in het kader van zijn scriptie ter afsluiting van de masteropleiding Communicatie- en Informatiewetenschappen, variant Communicatie \& Beïnvloeding aan de Radboud Universiteit Nijmegen onder begeleiding van Hans Hoeken.

\section{Bibliografie}

Appel, M., \& Maleckar, B. (2012). The influence of paratext on narrative persuasion: Fact, fiction, or fake? Human Communication Research, 48, 459-483.

Appel, M., \& Richter, T. (2007). Persuasive effects of fictional narratives increase over time. Media Psychology, 10, 113-134.

Banerjee, S. C., \& Greene, K. (2012). Role of Transportation in the Persuasion Process: Cognitive and Affective Responses to Antidrug Narratives. Journal of Health Communication: International Perspectives, 17, 564-581.

Busselle, R., \& Bilandzic, H. (2009). Measuring narrative engagement. Media Psychology, 12, 321-347.

Caputo, N. M., \& Rouner, D. (2011). Narrative processing of entertainment media and mental illness stigma. Health Communication, 26, 595-604.

Cho, H., Shen, L., \& Wilson, K. (in press). Perceived realism: Dimensions and roles in narrative persuasion. Communication Research.

Cohen, J. (2001). Defining identification: A theoretical look at the identification of audiences with media characters. Mass Communication and Society, 4, 246-264.

De Graaf, A., Hoeken, H., Sanders, J., \& Beentjes, J. (2009). The role of dimensions of narrative engagement in narrative persuasion. Communications. The European Journal of Communication Research, 34, 385-405.

De Graaf, A., Sanders, J., Beentjes, H., \& Hoeken, H. (2007). De rol van identificatie in narratieve overtuiging. Tijdschrift voor Taalbeheersing, 29, 237-250. 
De Graaf, A., Hoeken, H., Sanders, J., \& Beentjes, J. (2012). Identification as a mechanism of narrative persuasion. Communication Research, 39, 802-821.

Diekman, A. B., McDonald, M., \& Gardner, W. L. (2000). Love means never having to be careful. The relationship between reading romance novels and safe sex behavior. Psychology of Women Quarterly, 24, 179-188.

Green, M. C., \& Brock, T. C. (2000). The role of transportation in the persuasiveness of public narratives. Journal of Personality and Social Psychology, 79 (5), 701-721.

Green, M. C., \& Brock, T. C. (2002). In the mind's eye: Transportation-Imagery Model of narrative persuasion. In M.C. Green, J.J. Strange \& T.C. Brock (Eds.), Narrative impact: Social and cognitive foundations (pp. 315-341). Mahwah, NJ: Lawrence Erlbaum.

Green, M. C., \& Donahue, J. K. (2009). Simulated worlds: Transportation into narratives. In K. Markman, W. M. Klein \& J. A. Suhr (Eds.), Handbook of Imagination and Mental Simulation (pp. 241-254). New York, NY: Taylor \& Francis Group.

Hoeken, H. (2009). Narratieve evidentie, levendigheid en overtuigingskracht. Tijdschrift voor Taalbeheersing, 31, 169184.

Igartua, J. J. (2010). Identification with characters and narrative persuasion through fictional feature films. Communications. The European Journal of Communication Research, 35 (4), 347-373.

Igartua, J. J., \& Barrios, I. (2012). Changing real-world beliefs with controversial movies: Processes and mechanisms of narrative persuasion. Journal of Communication, 62, 514-531.

Moyer-Gusé, E. (2008). Toward a theory of entertainment persuasion: Explaining the persuasive effects of entertainment-education messages. Communication Theory, 18, 407-425.

Moyer-Gusé, E., \& Nabi, R. L. (2010). Explaining the effects of narrative in an entertainment television program: Overcoming resistance to persuasion. Human Communication Research, 36, $26-52$.

Moyer-Gusé, E., Chung, A. H., \& Jain, P. (2011). Identification with characters and discussion of taboo topics after exposure to an entertainment narrative about sexual health. Journal of Communication, 61, 387-406.

Preacher, K. J., \& Hayes, A. F. (2008). Asymptotic and resampling strategies for assessing and comparing indirect effects in multiple mediator models. Behavior Research Methods, 40, 879-891.

Raney, A. (2004). Expanding disposition theory: Reconsidering, character liking, moral evaluations, and enjoyment. Communication Theory, 14, 348-369.

Slater, M. D., \& Rouner, D. (2002). Entertainment-education and elaboration likelihood: Understanding the processing of narrative persuasion. Communication Theory, 12, 173-191.

Slater, M. D., Rouner, D., \& Long, M. (2006). Television dramas and support for controversial public policies: Effects and mechanisms. Journal of Communication, 56, 235-252.

Strange, J. J., \& Leung, C. C. (1999). How anecdotal accounts in news and in fiction can influence judgments of a social problem's urgency, causes, and cures. Personality and Social Psychology Bulletin, 25, 436-449.

Tal-Or, N., \& Cohen, J. (2010). Understanding audience involvement: Conceptualizing and manipulating identification and transportation. Poetics, 38, $402-418$.

Till, B., \& Vitouch, P. (2012). Capital punishment in films: The impact of death penalty portrayals on viewers' mood and attitude toward capital punishment. International Journal of Public Opinion Research, 24, (3), 387-399. 